\title{
STATUS OF COCONUT RESEARCH, DEVELOPMENT AND UTILIZATION IN TANZANIA
}

\author{
E. N. BALINGASA*
}

\begin{abstract}
Coconut is an important economic crop in the coastal belt of Tanzania and the island. However, production has been dwindling through the years due to various constraints, eg, poor plantation management, lack of improved planting materials, insect pests - notably Oryctes monoceros Oliv, and the coreid bug, Pseuclotheraptus wayi Brown plus a lethaf-disease presently belie to be caused by mycoplasmalike organisms.

To offset further decline of the industry, the National Coconut Development Programme was created by the Ministry of Agriculture and Livestock Development, assisted by the Federal Republic of Germany and the World Bank. Production promotion activities were implemented - conducting selection works on the East African Tall coconut population, establishment of seed gardens to produce high yielding planting materials and supporting extension to disserninate technical information. Simultaneously, researches in agronomy, breeding, pest and disease control were conducted. Lately, farming systems research was added as a new project component. Significant findings on the various research areas are discussed in this paper plus some aspects of utilization, processing and marketing.
\end{abstract}

\section{INTRODUCTION}

The coconut is presently believed to have originated frorn Southeast Asia or Micronesia (Harries, 1977; Purseglove, 1968; 1972) and came to the East African Coast via India or Sri Lanka. Historical trade connection between Asia and Africa, indicated by the discovery of Chinese coins of the eighth and ninth century at Kilwa and Mogadishu (Revington, 1936) and at Mafia (Robinson, 1937), perhaps brought coconut to the east coast of Africa (Kaiza, 1987). When the Arabs arrived in Zanzibar in the tenth century the existence of coconut palms had already been recorded at Malindi (north of Mombasa in Kenya) (Purseglove, 1968). In Tanzania coconut planting was probably promoted firstly by the Arabs in Kilwa and extended to Rufiji and Kisarawe. Secondly, by the Germans, particularly at Tanga region during their administration of the then Tanganyika between 1841-1914. Thirdly, and perhaps the most significant coconut expansion was promoted during the British rule after the first World war. Between 1918 and 1946, coconut planting was expanded in the Tanga and Pangani districts, mainly in the coastal belt of Mkinga, Gombero and along the Pangani River replacing sugar cane plantations (Swynnerton, 1946).

*National Coconut Development Programme P. O. Box 6226 Dar es Salaam, Tanzania 
Ecological factors. - Climatic and -soil factors are essential considerations in any crop agriculture. For coconut, the favourable climatic conditions are generally acknowledged to exist within 20 degrees North and South of the equator. In the coconut growing areas of Tanzania sunshine, temperature, relative humidity and wind velocity are favourable (Wuidart, 1980). It is rainfall that is limiting, indeed (Agrar-und Hydrotechnik GmbH, 1980). Even areas of high rainfall (Pernba, Mafia and Zanzibar with means over several years of $2166 \mathrm{~mm}, 1731 \mathrm{~mm}$, and $1590 \mathrm{~mm}$; respectively) experience severe drought during some years due to poor rainfall distribution resulting to 5-8 months of varying degrees of water deficit per year. In Lindi region, a mean of only $953 \mathrm{~mm}$ annual rainfall is not uncommon with about 9 months of water deficit. Nonetheless, coconuts are mainly grown in low lying areas where high water table compensates for low rainfall.

Soil conditions vary widely. More basic parent materials and various limestones have given rise to red, highly oxidic friable clays, classified as Rhodic or Orthic Ferassols (FAO, 1974). In more acidic and coarse-grained parent materials such as marls of the sandstones, the main soils are deep, reddish Luvisols or Acrisols. The really coarse-grained parent materials produce pale coloured deep sands, classified as Arenosols. Some of these deposits have humus mobilization and redeposition, so that there are also Orthic and Humic Podzols. The fine textured shales and maris give rise to extensive areas of dry cracking clays (Vertisols) and also to imperfectly and poorly drained soils (Gleysols). Gleysols occur on ail parent materials where there is waterlogging. In Zanzibar, Carlton et al. (1955) identified three main soll groups: mchanga - a catenary related group derived from noncalcareous sediment; kinong - red or potentially red soils of varying age derived from limestone; and kinano - a miscellaneous group of heavy soils, derived from clays and marls.

Agricultural sector, coconut and the economy. - The agricultural sector contributes $85 \%$ to exports, accounts for 40 of gross national product, and supports $90 \%$ of the population. It is a major source of food and raw materials for the urban and industrial sectors. The agricultural population is also an important market for the goods and services produced in the industrial sector. Agricultural development is therefore crucial to achieve the objective of employment, income distribution, sustalned growth and self-reliance on which the government has laid great emphasis.

Coconut is a crop of vital importance within the agrIcultural sector and the national economy as a whole. It plays the role of: 1) Income earner for the farmers in the rural areas of coastal Tanzama, where $15 \%$ of the country's population live and where there are few agronomic and economic alternatives to coconut; 2) source of vegetable oil in people's diet in rural areas; 3) importsaver through the supply of vegatable oil for the urban consurners; and 4) on the long-term, a potential forelign exchange earner for the nation through exports of copra, oil and other coconut products. Coconut is abundant in the coastal belt, from Tanga to Mtwara and in the islands of Zanzibar, Pemba and Mafia. It occupies about 240,000 ha, with 22.6 million trees, one-quarter of which is found in the islands. The crop is produced basically by the smallholders (95\%), the rest by medium and large scale commercial growers. Mean annual production is reckoned at 23 nuts per tree/year.

About one-third of the production is used for subsistence, the rest is largely sold as freshnuts; except in Zanzibar and in Mafia (Mafia Coconuts Ltd - MCL) where copra production and oil processing are still done. The crop provides some $40 \%$ of the total vegetable oil in Tanzania making it the single most important source of this oil. Market projections of the vegetable oil sector show that the present demand is much higher than the quantities available. Probably, one-half of the requirement is not met. With the rapidly increasing population this deficit would continue to exist unless the coconut output will be more than doubled by the year 2010. Any growth in per capita income would further widen the gap between supply and demand. This condition promotes a highly favourable socio-economic climate for the promotion of coconut, which has been characterized by a downtrend in production as a result of various factors: 1) generally low level of cultural management, especially with smallholders; 2) presence of overaged palms that arc declining in production; 3) poor quality 
planting materials; and 4) the incidence of insect pests and a lethal disease. These factors are further aggravated by the low rainfall pattern (except in Pemba, Zanzibar and Mafia) compared to other coconut growing countries (Balingasa, 1984).

Cognizant of these problems, the goverment seriously thought of an institutionalized body not only to arrest further decline but go much further to promote the coconut industry. Thus, the existence of the National Coconut Development Programme.

\section{THE NATIONAL COCONUT DEVELOPMENT PROGRAMME}

The National Coconut Development Programme (NCDP) begun in 1979, launched with the external assistance from the Federal Republic of Germany (FRG). InItially, It was intended to develop disease and pest control measures, examine the potential for introducing improved varieties and production of quality seednuts and planting materials, train Tanzanian staff in husbandry and extension methods, and support the coconut field advisory activities. Later, a Coconut Pilot Project, appraised in 1980 - effected in 1981 and with financial assistance from the International Development Association (IDA) of the World Bank was designed in close collaboration with NCDP to finance: 1) agronomy trials (varietal and husbandry); 2) improved main tenance and rehabilitation trials; and 3) technical assistance required for the implementation of the trial programme, consultancies, training of local staff and preparation of the planning documents for the next phase of the coconut development prograrnme.

To avoid overlapping and ensure cost-effectiveness, and to achieve close cooperation and coordination between the FRG and IDA-financed activities, IDA accepted the proposal of the Tanzanian Government that the Coconut Pilot Project would become part of NCDP. It was further agreed that the German Agency for Technical Cooperation (GTZ), which already implemented the FRG-supported component, should undertake management of NCDP under the overall responsibility of the Ministry of Agricultural and Livestock Development (MALD).

NCDP is managed by a Coordination unit under the overall responsibility of the MALDs in the Mainland and in Zanzibar. This Coordination Unit, supported by a small planning section, organizes budgeting and accounting. It is responsible for manpower planning and development and general administration, including procurement. A technical service section - equipped with the basic infrastructural facilities, tools and equipment, caters to repair of vehicles and equipment, with maintenance services at headquarters and field stations.

On the agri-technical aspect, the works done so far and the major results achieved can be classified into:

1) production promotion; and 2) research activities.

\section{PRODUCTION PROMOTION}

Development and operation of seed gardens. - Two seed gardens, one in Mafia Island and the other in Zanzibar were developed and operated to produce hybrid seednuts. These seed gardens were designed to adopt the "assisted pollination" technique of hybrid seednut production, characterized by separate solid block planting of mother and father palms. There is a built-in flexibility in such a clesign. A mere shift in the variety of pollen brought into the mother palm sites will produce a different hybrid. Thus, the life span of the seed garden is not out-moded with the discovery of a new or better hybrid, provided that the same mother palm variety is involved. Furthermore, there will be higher hybrid seednut output per unit area, in as much as more mother palms are planted per unit area. A number of varieties (Table 1) comprise the planted palms in the seed gardens. 
Table 1. Varieties in the seed gardens and hectarage planted, 1988 (a)

\begin{tabular}{|l|c|c|c|}
\hline \multicolumn{1}{|c|}{ Variety } & Zanzibar & Mafia & Total \\
\hline Mother palms (b) & $\underline{\text { ha }}$ & $\underline{\text { ha }}$ & $\underline{\text { ha }}$ \\
MYD & 31.61 & 35.00 & 66.61 \\
CRD & 9.98 & 11.41 & 21.39 \\
MRD & 9.98 & 11.00 & 20.98 \\
BGD & 2.41 & 1.70 & 4.11 \\
SGD & 4.74 & 0.00 & 4.74 \\
PRD & 1.93 & 0.00 & 1.93 \\
\hline Sub-total & 60.65 & 59.11 & 119.76 \\
\hline Father palms (c) & & & \\
EAT & 8.73 & 9.27 & 18.00 \\
WAT & 8.95 & 6.47 & 15,42 \\
RLT & 0.73 & 0.77 & 1.50 \\
PYT & 3.44 & 4.50 & 7.94 \\
KPT & 0.00 & 0.76 & 0.76 \\
MLT & 0.00 & 1.22 & 0.76 \\
THT & 0.00 & 23.75 & 1.22 \\
\hline Sub-total & 21.85 & 23.75 & 45.60 \\
\hline Total & 82.50 & 82.86 & 165.36 \\
\hline
\end{tabular}

(a) - Missing palms deducted.

(b) $\quad-205$ palms/ha

MYD - Malayan Yellow Dwarf

CRD - Cameroon Red Dwarf

MRD - Malayan Red Dwarf

BGD - Brazil Green Dwarf or

EGD - (Equatorial Guinea Green Dwarf)

SGD - Sri Lanka Green Dwarf

PRD - Pemba Red Dwarf (c) $\quad-143$ palms/ha (Talls)

EAT - East African

WAT - West African

RLT - Rennell

PYT - Polynesia

KPT - Kampuchea

MLT - Malayan

THT - Thailand

The seed gardens currently produce hybrids mainly of two types; MYD x WAT and CRD x WAT - hybrids approved for release. Production of hybrids started in 1985 (Table 2). Initially, pollen for the seed gardens had to be imported. But starting 1987, some pollen were produce locally; and in 1988, the seed gardens became self-sufficient in its pollen need. Thus, the end of pollen import.

Table 2. Hybrid seednut production in the seed garden, 1985-87 (a)

\begin{tabular}{|l|c|c|c|c|}
\hline \multicolumn{1}{|c|}{ Seed Garden } & 1985 & 1986 & 1987 & Total \\
\hline Zanzibar & 10,939 & 105,982 & 355,914 & 785,571 \\
& & & & \\
Mafia & 195,466 & 89,572 & 500,533 & 472,835 \\
\hline Total & 206,405 & 195,554 & 856,447 & $1,258,406$ \\
\hline
\end{tabular}

(a) - Gross figures, rejects account for about $30 \%$.

The 1985 yield in Zanzibar was considerably reduced due to the major damage caused by Pseuclotheraptus wayi Brown. Without implementing chemical control measures, hybrid seed production would have been practically nil in Zanzibar. This insect pest can really inflict very serious 
damage. Biological control measure of this insect pest using a preclator ant species, Oecophylla longinoda appears to be promising, but the level of colonization is just not enough to provide sufficient protection for the developing buttons. At peak production, granting that P.Wayi darnage can be contained and hybriclization done on all seed parent palms, the combined seednut production capacity can reach about 1 million per year. Depending upon environmental factors mainly rainfall, tremenclous yield fluctuations can be experienced. Nevertheless, under such seednut production capability, it is practical to assurne that seednut requirement for future planting (that which the inclustry can reasonably absorb for planting) can be adequately met.

Provision of East African Tall seednuts. - The base coconut variety in Tanzania is the East African Tall (EAT). It is a rather variable coconut population exhibiting distinct morphological nut features typical of: 1) the Mozambique Tall (MZT); and 2) the West African Tall (WAT). The former has prominent shoulders and the segments are characteristically flattish. The latter, on the other hand, exposes a ridge along the equatorial diameter of the nut when dead-ripe.

NCDP advocates the planting of both EAT and the hybrid. Thus, there is a need for large quantities of quality EAT seednuts. To guarantee this, a simple and practical mass selection technique had to be followed. In the long-run, EAT seednuts can be supplied from individually selected palms based on phenotypic choices, yield records and nut component data. In this case, the heritability values of certain characteristics are considered in deciding on the criteria of choice. However, one major limitation of individual palm selection is the low quantity of seednuts obtained, so that under high demand it may not be possible to meet the requirement adequately.

The final solution, however, in the supply of quality EAT seednuts is the development of an EAT seed garden. Todate, a first cycle of EAT selection had been carried out and palms were field planted in an aggregate area of about 20 ha. From these palms a second selection which must take into account growth characteristics, eg, precocity to flowering and resistance to pest and diseases, can be done. Thereafter, a new EAT seed garden can be established as a permanent source of improved EAT seednuts.

Extension services for coconut growers. - General extension services in Tanzania is directly functioning under the two MALDs - one for Mainland Tanzania and the other for Zanzibar. Under NCDP, extension services is a function relegated to Its organizational component called Coconut Extension Services (CES). The CES plays the role of a catalytic agent towards achieving increased coconut production through campaigns for adoption of appropriate cultural management practices relevant to the rehabilitation of existing coconut groves and the establishment of new plantations. In the case of the latter, CES is involved in providing quality planting materials by assisting in the selection of EAT seednuts and promoting the planting of hybrid materials, a direct output from NCDP's seed gardens. Adjunct to this, CES provides technical assistance in the operation and management of non-NCDP nurseries to ensure the production of quality seedlings. The CES does not have its own extension organization in the field. It functions as subject-matter specialist for the general extension service of MALD which provides the direct linkages with the coconut growers; (NCDP, 1987).

Extension service in coconut involves some 300,000 coconut growing families (farming under a mixed-cropping system), farm sizes varying from one to about ten hectares. There are few plantations, estimated to cultivate not more than 5\% of the total palm population. The working area of CES covers five regions with,25 districts in,the mainland and 10 districts in Zanzibar (Unguja and Pemba).

In mainland Tanzania, CES consists of several organizational units: 1) management unit composed of a counterpart staff arid an expatriate advisor; 2) information arid training unit with two 
officers; 3) nursery development unit - with three officers; 4) regional units - one regional coconut extension officer in each of the five regions; arid 5) estates unit - with one officer-in-charge catering to the needs of estate plantations/large scale commercial growers (Barkey, 1988). All these officers are employees of the MALD.

\section{RESEARCH ACTIVITIES}

Research activities in coconut are presently confined to the areas of agronomy, breeding, disease, insect pests, arid farming systems research. Agronomy deals on aspects related to cultural management practices, mineral nutrition, and testing of varieties arid hybrids under various agro-climatic conditions. Breeding research deals with the improvement of the EAT, conservation of local genetic variability. Introduction of germplasm, plans to undertake genetic combining ability tests arid to pursue problemspecific investigations on areas related to seed production. Disease control research deals with the lethal disease (LD), a serious malady that besiege the industry arid could be a major determining factor on the future of coconut in Tanzania. Pest control, on the other hand, deals with Oryctes monoceros arid Pseudotheraptus wayi - two major economic insect pests in the country today. Farming systems research deals with agronomic arid socio-economic aspect of coconut production and their propriety as technological inputs in the entire coconut based farming systems, especially for smallholders.

\section{Agronomy Research}

Trials in agronomy research (started in 1981) relate to aspects of fertilizer/plant nutrition, variety/hybrid testing, arid husbandry/ cultural management. These trials are carried out in nine trial sites selected as typical of seven major potential coconut growing areas: 1) red-btown sandy loam (Mkuranga); 2) coastal sands (Chambezi/Kange); 3) brown-red clay (Maramba/Mlingano); 4) red sandy clays over corals (Boza); 5) alluvial (Nga'apa); 6) sandy loam (Zanzibar); arid 7) red clays over corals (Zanzibar). In addition, agronomic performance of varieties arid hybrids in the disease resistance trials are recorded.

Fertilizer/plant nutrition. - Among trials related to fertilizer/plant nutrition on Mainland Tanzania, some interesting results were noted, briefly summarized as follows (Romney, 1987):

In the red-brown sandy loams, nut production was increased substantially by phosphorus (P) arid less by nitrogen $(\mathrm{N})$. Nut size was increased by potassium $(\mathrm{K})$ arid complete cultivation produced more nuts than large weeded circles. At obtaining prices of 1987 , fertilizing with $\mathrm{P}$ arid complete cultivation were the most profitable practices.

On coastal sand, nut production was increased by $\mathrm{N}$ arid by $\mathrm{K}$, also by complete cultivation rather than weeded circles. Nut size was increased by K. Palm wilt caused by 1985-6 drought was less where $\mathrm{K}$ was applied under complete cultivation.

On red brown clays, nut production was improved by $\mathrm{N}$ on hybrids, but only in the absence of lime. EAT previously overfertilized with sulphate of ammonia (SA) responded to lime, nut size also improved. On all fields complete cultivation was much better than weeded circles.

In Zanzibar on Kichanga soil (sandy loam), it was noted that precocity arid early bearing of MYD x WAT hybrids were improved by N arid P. Among palms planted in April 1981, by December 1986, 12\% more bunches were produced if $\mathrm{N}$ or $\mathrm{P}$ were applied. The number of nuts tended to be greater with $\mathrm{P}$ in 1986, but nut set data at June 1987 did not show clear fertilizer response due to $\mathrm{P}$ wayi interference. Nut size averaged 5.1 nuts/kg copra. On Kinongo soil (red clay), growth arid 
precocity of MYD x WAT hybrids arid EAT were enhanced by $\mathrm{N}$ arid $\mathrm{K}$ together. Lack of $\mathrm{K}$ caused marked leaf deficiency symptoms accentuated by $\mathrm{N}$.

Variety/hybrid trials. - Trials of various planting materials (mainly hybrids) started in April 1981 arid some results have been obtained (Table 3).

Table 3. Percent bearing palms (6/87) as \% of MYD x WAT at Mkuranga, Chambezi and Bambi variety trials I and II

\begin{tabular}{|l|c|c|c|c|c|}
\hline \multicolumn{1}{|c|}{ Variety } & Mkuranga & Chambezi & Maramba & Bambi & Mean \\
\hline MYD x PYT & 129 & 98 & 107 & 93 & $107 \mathrm{a}$ \\
MYD x SLT & 45 & 143 & 138 & 109 & $109 \mathrm{a}$ \\
MYD x WAT & 100 & 100 & 100 & 100 & $100 \mathrm{a}$ \\
WAT x SGD & & & 104 & 90 & \\
CRD x WAT & 51 & 95 & 132 & 139 & $104 \mathrm{a}$ \\
EGD x EAT & 68 & 83 & 134 & 106 & $97 \mathrm{a}$ \\
MRD x WAT & 147 & 105 & 116 & 91 & $115 \mathrm{a}$ \\
CRD x PYT & 28 & 38 & 125 & 134 & $83 \mathrm{ab}$ \\
MRD x PYT & 131 & 96 & 82 & 101 & $103 \mathrm{a}$ \\
CRD x RLT & 49 & 55 & 77 & 143 & $81 \mathrm{ab}$ \\
EGD x WAT & 38 & 98 & 132 & 123 & $98 \mathrm{a}$ \\
CRD x EAT & 51 & 98 & 123 & 149 & $105 \mathrm{a}$ \\
WAT x RLT & 59 & 75 & 21 & 25 & $45 \mathrm{bc}$ \\
EAT & 32 & 53 & 25 & 3 & $28 \mathrm{c}$ \\
\hline LSD (0.05) & & & & & 47 \\
\hline
\end{tabular}

Agronomy - Annual Technical Report, 1986/87

In general, the various dwarf $\mathrm{x}$ tall hybrids were mutually equal in performance. There was no indication that EAT or MLT crosses were worse than WAT, RLT or PYT crosses. The WAT x RLT hybrid was less precocious than the dwarf $\mathrm{x}$ tall hybrids, but the nuts were larger. The tall varieties, to date, performed much more poorly than any dwarf $\mathrm{x}$ tall hybrid (especially in terms of growth and precocity) and usually worse than WAT $x$ RLT. There was a tendency for RLT to be better than other talls.

Husbandry/cultural management. - It was noted that field planted polybagged seedlings were $15 \%$ and $11 \%$ larger than bare-root seedlings, 22 and 34 months after planting; respectively. On ail soils, except red-brown sandy loam (where $\mathrm{P}$ deficiency occurs) weed control by cultivation was more effective than fertilizer. With intercropping (crops like banana, maize, pineapple, green grarn, sweet potato and cowpea), growth and bearing were much improved on ail soil types. However, only maize on red-brown clays was reliably profitable.

Other observations in agronomy trials. - The above information were some of the salient results obtained to date from. among the trials considering that the oldest planting was established only in 1981. P. wayi was observed to complicate and affect negatively, data on yield. It caused low fruit setting and deformed nuts. The number of nuts was inversely proportional to the percentage of nuts damaged by the pest. There was no difference in the reaction of the various varieties/hybrids to the

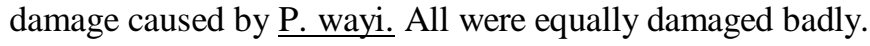




\section{Breeding Research}

Little has been done on coconut breeding research in Tanzania. In the 1930's, a selection work on the EAT was undertaken in Zanzibar (Johns, 1938). Unfortunately, the progenies planted as a result of this selection are nowhere to be found. In 1960's, another selection work was pursued in Chambezi and selected progenies were planted which are presently maintained for further breeding works. In Tanga (1970's), the first step to coconut improvement through hybriclization was initiated crossing EAT x PRD and a hybrid trial was established to evaluate the performance of the hybrid. It was clearly evident that precocity of the dwarf was transmitted down to the hybrids and the hybrids showed definite yield advantage over the control EAT.

Selection from 1980. - With the creation of NCDP, further selection was done on the EAT population. In connection with the establishment of seed gardens, EAT selection was initiated in Mafia in cooperation which MCL. From some selected palms, pollens were collected to produce crosses with EAT, hybrids of which are now being tested. A survey for coconut genotypes was undertaken in the major coconut growing areas (Balingasa et al., 1981). Three dwarf coconut populations, namely: Pemba Red Dwarf, Malayan Yellow Dwarf and Malayan Green Dwarf were identified. It was observed that in the EAT population, a great deal of variability exist among nut component data. Mean copra per nut was $175 \mathrm{gm}$, equivalent to 5.7 nuts $/ \mathrm{kg}$ of copra. Resulting from this survey, six locations - 4 in Zanzibar and 2 in Pemba, were identified as interesting EAT sub-populations and observed further for palm yields and nut component characters. At the same time, observation at MCL and Chambezi among selected palms based on pure phenotypic choices was carried out. Progenies from selected palms of the EAT sub-populations observed in Zanzibar and in Pemba were planted in Bambi and Kidichi, Zanzibar. From the observation at MCL, palms were selected as seednut sources for the establishment of pollinator palms in Mafia (Tirene) and in Zanzibar (Bambi), aggregating to more than 15 ha. Further selection is contemplated from these planted progenies out of the first selection cycle. From Chambezi, a number of palms were selected as interim seednut sources for small scale EAT planting.

Introduction of germplasm. - As part of the establishment of the seed gardens, the conduct of variety trials and the test for resistance to the lethal disease a number of coconut varieties were introduced (Table 4). Among the crosses involving EAT, pollen from EAT was provided by NCDP for producing hybrids at IRHO, Port Bouet, Ivory Coast since the dwarf mother palms planted in the seed gardens were not flowering by then. Expected to be received in 1988/89 from IRHO are Panama Tall, Kar kar Tall, Tagnanan Tall and Roturna Tall. It is planned that the various introductions not included in the present disease resistance trials are, also exposed to the disease in search for possible resistance. Varietal resistance may be the only plausible solution to the lethal disease problem. Furthermore, it is also hoped that varieties/hybrids which can reasonably tolerate drought conditions can be found.

Breeding stations and future activities. - One breeding station is being established in the Mainland at Chambezi. Complementary to this are the established seed gardens in Mafia and in Zanzibar which will play a great role in producing the hybrids using the already established varieties. In the future, it is envisaged to pursue activities concerning genetic combining ability testing, establishment of genetic trials and research on appropriate breeding techniques to support the seed production units. It is likely that EAT will play a dominant role in the future conduct of breeding research.

\section{Disease Control Research}

It is believed that for at least 80 years now, a destructive disease exists in Tanzania mainland. Reports about the disease are contradictory. A disease called Herzfaule (heartrot) was reported as early as 1905 near Bagamoyo exhibiting symptoms as: 
(a) THT obtained from Thailand, King Coconut from Sri Lanka and the rest from IRHO, Port Bouet, Ivory Coast; except MGD and EAT which were collected from Tanzania. These germplasms are established in either the seed gardens, disease resistance trials, and/or in the agronomy trials. NFIT - New Hebrides Tall, SLT - Sri Lanka Tall.

Table 4. Present coconut germplasm in Tanzania, 1988 (a)

\begin{tabular}{|c|c|c|c|c|}
\hline No. & Dwarf & Tall & $\mathrm{DXT} / \mathrm{TxD}$ & TxT \\
\hline $\begin{array}{c}1 \\
2 \\
3 \\
4 \\
5 \\
6 \\
7 \\
8 \\
9 \\
10 \\
11 \\
12 \\
13 \\
14 \\
15 \\
16 \\
17 \\
18 \\
19 \\
20\end{array}$ & $\begin{array}{l}\text { MYD } \\
\text { MRD } \\
\text { CRD } \\
\text { SGD } \\
\text { EGD } \\
\text { MGD }\end{array}$ & $\begin{array}{c}\text { WAT } \\
\text { RLT } \\
\text { PYT } \\
\text { MLT } \\
\text { KPT } \\
\text { THT } \\
\text { NHT } \\
\text { King Coconut } \\
\text { EAT (loca) }\end{array}$ & $\begin{array}{l}\text { MYD x WAT } \\
\text { MRD x WAT } \\
\text { CRD x WAT } \\
\text { BGD x WAT } \\
\text { MYD x EAT } \\
\text { MYD x PYT } \\
\text { MYD x NHT } \\
\text { MYD x MLT } \\
\text { MRD x EAT } \\
\text { MRD x PYT } \\
\text { CRD x EAT } \\
\text { CRD x RLT } \\
\text { CRD x MLT } \\
\text { CRD x SLT } \\
\text { BGD x EAT } \\
\text { BGD x NHT } \\
\text { WAT x SGD } \\
\text { MRD x MLT } \\
\text { MYD x SLT } \\
\text { CRD x PYT }\end{array}$ & RLT x WAT \\
\hline
\end{tabular}

premature nutfall, blackening of opening inflorescences and rot of the central leaves (Schuiling, 1987). Bacteria were considered to be the cause. Herzfaule was responsible for serious losses as well in young plantings near Mtwara in 1912-14. Bock et al. (1970) described a disease (Lethal Bole Rot) from the coast of Kenya and Tanzania, characterized by a primary bole rot, followed by frond wilt and crown rot. The fungus Marasmiellus cocophilus was implicated as the cause. It occurs predominantly on seedlings and young palms up to 8 years old. In Tanzania, it was reported to be most damaging in Kibiti, Pande and Rushingi. Steiner (1976) investigated a disorder near Tanga. However, he observed no rot in the heart or the bole. The most typical symptoms were drying up of successively younger fronds with the midribs breaking and the arrest in growth of immature inflorescences. Rickettsia like organisms were associated with the disorder. Steiner reported symptoms similar to Lethal Yellowing (LY) from Bagamoyo, Kabiti, lower Rufiji delta and Pande.

With the formation of NCDP to promote the coconut industry, a section for disease control was set-up to deal with the above mentioned disease and other coconut diseases as may be necessary. This section has been operational since December 1979.

Symptomatology of Lethal Disease. - Since 1980 many coconut palms of all ages, in various stages of the disease, were dissected and symptoms recorded. Symptoms were consistent in all affected areas and very similar to those of LY (a destructive disease in the Caribbean and some parts of West Africa). These were premature nutfall, bronzing of successively younger leaves, blackening of opening inflorescences, necrosis and rot of the spear leaves, and decay of the root system, in that order 
(Schuiling et al., 1981). Symptoms in non-bearing and bearing palms were similar, though restricted in range. The palms invariably die, the syndrome lasts 2-3 months in young palms and 5-7 months in mature palms. Palms are rarely infected before the age of 2 years. As co-identity with LY cannot be proven it was decided to name the disease - Lethal Disease (LD) of coconut palm.

From the numerous palms dissected, no bearing palm on the mainland showed a bole-rot as described by Bock (1970). In nonbearing palms such a rot was occasionally observed but only in advanced stages of LD, certainly not primary bole-rot. It is uncertain whether Lethal Bole rot disappeared from Tanzania or never existed at all (Schuilling, 1987). Symptoms as described from Tanga by Steiner et al. (1977) were occasionally observed but always associated with drought. Symptoms described in 1900's and by Steiner in 1976 are consistent with the symptoms for LD described above, indicating that LD has existed in Tanzania for a long time.

Etiology of LD. - Search for the causal organism of LD was done in cooperation with the Institute for Plant Disease, University of Bonn. Tissue samples from diseased palms were sent to Bonn for investigation with the electron microscope (EM) and ultrafluorescence microscope (UF). Work with UF was done in Tanzania as well. After initial negative results, mycoplasmalike organisms (MLO) were found in diseased palms, never on healthy palms (Nienhaus et al., 1981) It appeared that MLO could only be detected if the EM work was focused on tissues with DNA accumulation in the phloem as demonstrated with the UF using DAPI, a fluorescent dye which reacts with the DNA of invading micro-organisms to form a fluorescent complex. The simple DAPI-technique was then used as a pre-test facilitating the cumbersome and quantitatively restricted work in the EM. No bacteria, Rickettsia-like organisms or fungi were isolated from diseased palms. The spotting of MLO means that these organisms are likely to be the cause of $\mathrm{LD}$, though this canot be proven yet. Thus, investigation is in progress.

The injection of both bearing and non-bearing diseased palms with tetracycline-hydrochloride antibiotic resulted in the remission of symptom but only if injection was started in sufficiently early stage of LD. Total remission of symptom was observed in one bearing palm only, the other remitting palm showed delayed symptom development compared with their controls and succumbed later. Tetracyclines are antibiotics which act against MLO in disease palms support the concept of a MLO-etiology for LD (Kaiza, 1987). However, it is not intended to use tetracycline as a control method because remission of symptoms was only temporary and it is highly uneconomical.

Recently, the planthoppers Myndus crudus and Myndus taffini were implicated as vectors of coconut diseases elsewhere. Insect population studies at seven LD-affected sites revealed that the insect species on coconut in Tanzania are virtually planthoppers as well. Twenty nine different species were identified at the $C A B$ Institute of Entomology of which only seven were common at all sites. These seven species are the most likely candidates as vectors of the agent causing the LD. In transmission trials to find the vector of the LD, only one test plant developed symptoms of the disorder similar to LD. However, for several reasons the case is doubtful and has to be confirmed.

Epidemiology of LD. - Maps of LD incidence in the project area are from 1982 and currently brought up to date. LD occurs only on the Mainland Tanzania. The severity of LD incidence in affected areas varies greatly from low activity to rampant disease, a phenomenon with no concrete explanation as yet. Low incidence in old EAT groves does not necessarily tally with low activity in young plantings. At several trials and private plantings alarming losses occured on young plants while they were low or $\mathrm{ml}$ in the mature surrounding palms. Even where LD is rampant, the rate of spread is comparatively low. New outbreaks were observed but often did not become established. Unlike the aggresive spread of LY with frequent "jumps", LD spread more like an oil stain (Schuiling, 1987). Newly diseased palms are recorded periodically in five extension fields of mature EAT and all young plantings of NCDP in diseased areas. Early observations indicated that: 1) LD causes the heaviest 
losses in the periphery of coconut groves, in particular where they are exposed to the prevailing wind; 2) that young plantings surrounded by other palms or bush are less quickly infected;2) that symptoms occur predominantly from December till June; and 4) shading by mature palms decreases the rate of infection in young plantings.

Search for LD-resistance. - Research on the LY for the last three clecades inclicated that the most important, if not the only way to control the disease is the search for resistant varieties. Therefore, disease resistance trials were established at six different LD-affected areas, naturally exposing the various varieties to the disease as this is the only way, so far, to test their resistance. Varieties on tests (Table 2), except for THT and King coconut -respectively imported from Thailand and Sri Lanka, were imported from IRHO, Port Bouet, Ivory Coast. The EAT is used as a local control. It was noted that the hybrid MYD x WAT is not promising as to resistance. There was no certainty that other hybrids would perform better (Schuiling, 1987). Incidence of LD during 1986/87 had increased heavily in the trials. Losses in the MYD reached 19.7\% in Kifumangao while MRD was at $4.8 \%$, still satisfactory. in terms of resistance. The Brazil Green Dwarf performed worst at 30.6\% loss. The CRD at $10.0 \%$ loss and SGD at $12.6 \%$ need further observation. There appeared to be little differences in losses between the talls and the hybrids, indicating that satisfactory resistance in the dwarfs (the assurned bearer of the resistance factor in the hybrids) may not exist. Nevertheless, a survey in Tanzania on Baculovirus in the natural population of $\underline{\mathrm{O} \text {. monoceros, }} \underline{\mathrm{O} \text {. gigas and } \mathrm{O} \text {. boas }}$ revealed no trace of this, virus. Thus, introduction was imperative. In the case of $\mathrm{m}$. anispliae, however, strains of the fungus do occur naturally In all immature stages and adults (Seguni et al., 1987).

(i) Studies with Baculovirus oryetes. - Three isolates of B. oryctes: from $\underline{\text { O. rhinoceros introduced }}$ from Western Samoa (SV), the Philippines (PV) and the Seychelles (SEY) were experimented, upon to investigate their respective virulence on $\underline{\mathrm{O}}$ monoceros beetle in Tanzania, using a standard, dose of $10^{-}$ ${ }^{4}$ virus-diseased midgut in the test, of infectivity. Infection rates of $60-80 \%$ were usually obtained with PV isolates. In some - cases, infection reached as high as $90 \%$. SEY isolates gave consistently low infection rates of $16-40 \%$ on $\mathrm{O}$. monoceros from Tanga and Zanzibar, while the same isolate

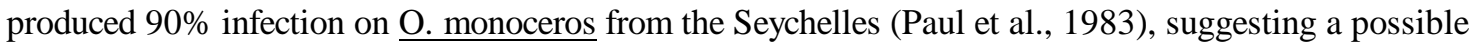

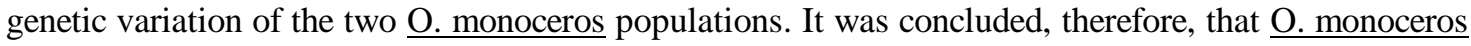

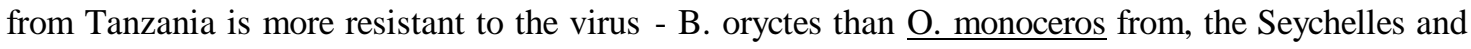
$\underline{\text { O. rhinoceros }}$

After some experiments, the' $\sim^{\prime} V^{\prime}$ virus strdin:was suggested for release (Paul et al, 1983). However, in later transmission ekperiments (Purrini et al., 1984) a rather low infection rate of 40-60\% was consistently observed. Thus, piompting further experimentation including the use of mixed strains, ie, $\mathrm{PV}+\mathrm{SV}, \mathrm{SEY}+\mathrm{SV}, \mathrm{PV}+\mathrm{SEY}$, and SV + PV + SEY. The PV + SV combination was proven highly pathogenic with $80-100 \%$ infection rates. These mixed strains were therefore released. Possibly, this enhanced infectivity of the mixed strains can be due to some synergistic effects of the two strains in combination. No differences were detected by electron microscopy from the a0pearance of the viral rods belonging to PV $+\mathrm{SV}, \mathrm{PV}, \mathrm{SV}$ and SEY. Thus, the nature of the PV + SV cannot be ascertained. Serological studies; may provide the answer.

The culminating aspect on the virus study was the field release of virus infected adult beetles for biological control of $\underline{O}$. monoceros by transmitting the infective virus to healthy beetle population.in the environs mainly during the copulation process. Monitoring of the release showed an establishment of the virus in nature. The trap and field-collected adults showed symptoms in the nuclei of their gut cells which were undoubtedly due to virus infection. The infection rate averaged $31.0 \%$ and $22.3 \%$ from all these reactions of the dwarfs and the hybrids must be interpreted with caution. The dwarfs and the hybrids are more precocious than the tall and may have reached the susceptible age earlier. Losses may level off or lessen in degree with age in the hybrids and perhaps increase in the 
talls as the talls reach a physiologically susceptible stage. In the light of current results, it is important to extend LD-resistance testing to other varieties. On the EAT, great differences in losses among the various disease areas indicate that possible resistance may exist in the local EAT population. The best performing tall in relation to the LD disease was noted with EAT collection from LBS, Tanga. Loss was at $3.0 \%$ against $38.5 \%$ loss with the worst entry in the trial at Pongwe, Tanga. It was therefore decided to intensify search for LD resistance in the EAT population.

Other disorders of coconut in Tanzania. - In the nursery, it was observed that blast, dry bud rot and leaf spots are common diseases. Blast caused significant loss in one nursery where it was observed most active from August to October. Perhaps, the incubation started as early as July. Other disorders such as weakening of the palms and loss of turgidity were observed to be pure physiological disorders ascribed to extreme cases of drought.

\section{Pest Control Research}

Pest control research concentrated on two major coconut pests, namely: the beetle - Oryctes monoceros Oliv. and the coreld bug - Pseudotheraptus wayi Brown. Initially work was focused on the beetle, damage of which can be observed on palms of all ages. In plantations the beetle may turn into a serious pest when attacking young palms. The Impact of beetle damage on young palms is much higher and can lead to death of the palms. Among bearing palms, economic damage is more manifested as reduction in yield due to destruction of green leaves, thus reducing photosynthetic capability of the palms. On both pests, the beetle and the coreld bug, certain studies were undertaken and some results have been obtained.

Oryctes monoceros and its control. - Investigations carried out centered more on the biological control of the beetle, using the virus Baculovirus oryctes Huger and the fungus Metarrhizium anisopliae (Metch.) Sor. with bias on the former. The virus has been known to be pathogenic to other rhinoceros beetle species including O. monoceros (Julia et al., 1976). Unfortunately, specimens diagnosed for virus from Vuo-Gezani and Magawa (the two release areas), respectively. Presence of the virus in the field was also demonstrated by biological assay experiments using suspected virus-infected guts from beetles collected in the release areas. Such guts were macerated, prepared as inoculum and tested on healthy beetles, some of which developed symptoms of virus infection after four weeks of incubation. Specimens were also prepared for electron microscopy and the micrographs of a specimqn from Vuo-Gezani area showed virus development in the initial stage. However, in many-cases where a specimen was diagnosed as positive, the full virus symptoms were not yet developed. Many nuclei of beetles diagnosed as positive were clearly hyperthropicied, accompanied by initial disintegration of chromatin. In some cases, the nuclei showed abnormal hyperthropy without any other accompanying symptoms. This weak expression of the virus symptoms might be expected for the following reasons (Seguni et al., 1987): 1) resistance of O. monoceros to the virus; 2) Possible lower close of the virus taken by the insect through accidental infection - perhaps much lower than the inoculation dose in the laboratory; 3 ) diagnosis of perhaps relatively healthy specimens, since beetles which contracted higher dose of the virus might had been "so sick" that trap collection was. no longer effective; and 4) insufficient sensitivity of the diagnostic method to detect weaker

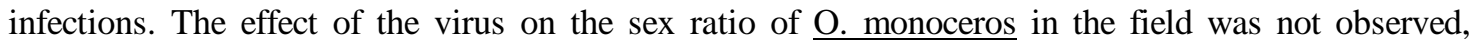
Orobably due to low infection percentages - 31.0\% in Vuo-Gezani and $22.3 \%$ in Magawa. In O. rhinoceros, Zelazny (1979) noted a female-blased field population ratio where the virus was successfully established. This was clue to higher percentage of virus transmission from females to males than vice versa. Similar phenomenon was observed in Seychelles (Lomer, 1986) on O. monoceros, but under field infection percentages of up to $50 \%$.

Post-release figures from damage surveys in Vuo-Gezani and Magawa showed a decline in the damage level. Damage levels in Vuo-Gezani ranged from 30-45\% before the release to $10-20 \%$ after 
24 months from release. At Magawa the pre-release damage ranged from 70-70\% while the range 12 months after release was reduced to $37-54 \%$.

From these studies, the following conclusions were drawn: 1) B. oryctes is infecting $\underline{O}$. $\underline{\text { monoceros, }}$ although the effects of the virus are reduced, compared to effects on $\underline{\mathrm{O} \text {. rhinoceros. The }}$ almost sterilizing effect of the virus infection on $\underline{O}$. rhinoceros was not observed on $\underline{O}$. monoceros; 2 ) the virus was transmitted from diseased to healthy adults of $\underline{\text {. }}$ monoceros; 3) a mixed infection of virus from the Philippines and from Western Samoa produced better infection rates on O. monoceros than infection with any single strain; 4) the virus released in the $\mathrm{O}$. monoceros population in Vuo-Gezani and Magawa is established in both areas; 5) the virus was still present two years (Vuo-Gezani) and 16 months (Magawa) after release; 6) the percentage virus infection of beetles collected in attractant traps was about $30 \%$; 7) virus symptoms in the collected beetles were weak and difficult to diagnose with light microscopy; and 8) damage caused by the beetles at the release areas was reduced compared to the damage prior to the release, but the differences were not big enough to allow final conclusion. Therefore, the observations will be continued for another year. Experiments on virus transmission among adults under field conditions, effect of virus infection on the reproduction of the beetles, and effect of virus infection on the flight activity should be conducted before the release programme is extended to other areas of high beetle population.

(ii) Studies on Metarrhizium anisopliae. - The green muscardine fungus - Metarrhizium anisopliae (Metch.) Sor. was first recorded as a pathogen of O. rhinoceros in Samoa (Friederichs, 1913). Since then, several attempts were made to use this fungus as a microbial insecticide in various part of the world with varying degrees of success. This fungus occur in nature, although at low incidence. The fungus develops through several stages while infecting to cause death of the host: 1) infective spores in the natural environment attach themselves to the insect cuticle; 2) the spores germinate and penetrate through the epicuticle; 3 ) penetrant hyphae multiply throughout the hemocoele (body cavity); 4) toxic metabolites cause degeneration of the host tissue; 5) the host dies; 6) the fungus continues saprophytic growth and spreads through all tissues; and 7) hyphae sporulates on the host surface and produce new infective spores.

In Tanzania, very few naturally infected insects were found. Perhaps the fungus is in such a low level in the natural environment that epizootics do not occur (Allard, 1984). Nonetheless, from the screened infected larvae and adults, a highly pathogenic long-spored strain designated as M 30 (11.5 microns) was isolated in October 1982 from a locally infected $\underline{\text { O. monoceros adult. The fungus was }}$ multiplied on dextrose agar medium and grown saprophytically of sorghum. This isolate was mass produced in Zanzibar using maize (due to local availability) instead of sorghum. It was noted that in the mass production process the contamination of Penicillium sp inhibited production of Metarrhizium spores. Under laboratory conditions, pathogenicity tests with the fungus gave very promising results, likely because of controlled environmental conditions which promote growth of the fungus. Infected larvae developed a creamy colour, stopped feeding and became moribund. The body hardened clue to ramification of the hyphae throughout the body cavity. Soon the insect died and white hyphae appeared on the integument. Approximately two days later, characteristic green spores appeared on the integument. Tupae infected during the third instar larval stage took about 25 days before death. The appendages became deformed and the body shrunk. The body contents hardened and spores appeared between the segments. With adults, spores were observed on the inter-segmental membranes of the leg joints and on the neck and antennae. The whole body cavity became filled with hyphae.

The encouraging results in the laboratory warranted field release of the fungus. In the field, however, the results did not substantiate well the finclings in the laboratory. Also, continuous maintenance of a laboratory to mass produce the fungus for field release had to be sustained making it an uneconornical control agent. Foremost, however, the natural climatic conditions in coconut growing areas of Tanzania may not be conducive to promote growth and maintain an adequate amount of 
inoculum due to dry conclitions and higher temperatures. It is known that infection in nature is favoured by high humidity, relatively low temperatures and of course high quantity of inoculum potential. Thus, prompting the termination on any further investigation about the fungus as a potential biological control agent.

(iii) Other studies related to O. monoceros. - Investigations carried out from December 1983

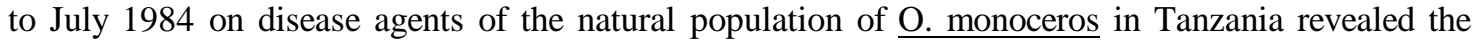
presence of different parasites belonging to bacteria, rickettsialike organisms, fungi, protozoa and Helicosporidium sp (Purrini, 1984). Fungi, other than M. anisopliae, probably belonged to the genera: Aspergillus, Beauveria and Entornophtora. Field infection was low, approximately 1-2\%. The bacteria

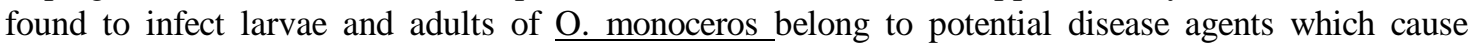
infection usually when the host is weakened or under stress (Bacillus sphaericus, B. cereus, Clostridium sp, Pseudomonas s arid Achromobacter sp. The infection rate of 1-3larvae during mass rearing ranged from $10-60 \%$, arid adults $0-10 \%$. Some micro-organisms similar to Reckettsia were also found to infect L3-larvae in wild palms. On the protozoan parasites, a neogregarine Ophryocystis oryctes Purrini, two microsporidians - Pleistophora tanzaniae Purrini and Oryctos phora neddenriepi Purrini were found to infect $\underline{O}$. monoceros. Helicorsporidium $\mathrm{sp}$, a parasite infecting only

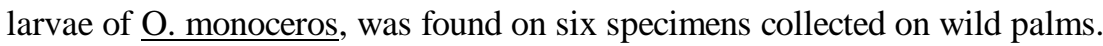

Other control measure studies against $\mathrm{O}$. monoceros included mechanical control, through field sanitation arid destruction of breeding sites (burning and stacking of logs to facilitate faster decomposition - indexing arid checking for beetles in the process plus direct hooking of beetles in palms) arid chernical control through insecticide arid repellants applied directly to the palms. It was found that Aldrin afforded limited protection. Insect repellant trials using neem extracts-sand mixture gave little or no effect.

Pseudotheraptus wayi and its control. - The coreid bug -Pseudotheraptus wayi Brown is undoubtedly a very serious pest in Tanzania, economic importance of which was underestimated, initially. Devastating damage was noted in the young coconut seed garden at Selem in Zanzibar, where hybrid seednuts are, produced. From March to December 1984, when emasculation arid pollination works were started for hybri d seednut production, a total of 15,854 inflorescences were emasculated. Out of these emasculations, yield for 1985 (if free from the negative effect of biotic arid abiotic factors) was estimated in the vicinity of 100,000 seednuts. However, due to the coreid bug only about 10,000 hybrid nuts (badly damaged arid visually unfit as seednuts) were harvested, despite the good number of fernale flowers; per inflorescence plus the vigorous development of the palms. In Zanzibar, Way (1953) showed several folds of yield increases following insecticidal treatments. In 1954 (Vanderplank) observed similar results, the annual yield being increased from 4.64 nuts/palm to 58, although P. wayi was only partially controlled (Keyserlingk, 1985). Vanderplank (1959) also recorded an increase in yield from 8.5 nuts/palm to 78,8 nuts/palm in 1955 following successful establishment of colonies of Oecophylla longinoda Latreille, an ant species that if present, prevents the damage of P. wayi. It was concluded in $1959 / 60$ in Zanzibar that about $67 \%$ of the potential crop was lost due to the bug. More recent data for Zanzibar (Way, 1983) showed yields on the five oldest spadices as 33 nuts/palm on $\underline{O}$. longinoda-colonized palms compared with about 14 nuts among palms occupied by other ants. The corresponding figures from Tanga region were 26 and 19, and from Bagamoyo - 23 and 12. This does not account for the decreased yield on the economic products of damaged nuts which developed to maturity. The proportion of damaged nuts in O. longinoda-colonized palms ranged from 1 to $10 \%$ according to region and in palms occupied by other ants the damaged nuts were $67 \%$ in Zanzibar, 51\% in Tanga and 54\% in Bagamoyo (Way, 1983).

(i) Chemical control of $\mathbf{P}$. wayi. - The impact of P. wayi damage was best appreciated with the hybrid seed production at the seed garden in Zanzibar. To control the bug, Lindane $20 \%$ EC (gamma BHC) was sprayed to the opening inflorescences and the developing bunches of about 4 
months old and younger at a starting concentration of $0.26 \%$ of the commercial product. Initially, spraying was at 2-week interval which was later extended to 3-4 weeks depending upon the degree of damage observed in the youngest developing bunches. In the 1950's dusting with $0.4 \%$ gamma BHC was found effective against the bug (Way, 1953). It was evident that without insecticide treatment no yield could have been realized in the seed garden, even up to the present.

In 1986, Dimethoate 40\% EC (253 g al/ha), Dicarzol $50 \mathrm{WP}$ (Formethanate at $500 \mathrm{~g}$ ai/ha) and Thiodan 35\% EC (endosulfan at $221 \mathrm{~g}$ ai/ha) were tested in the seed garden. Thiodan was the most effective, had good activity against the coconut mite (Aceria guerreronis) and was not harmful to the weaver ant, O. longinoda (Oswald, 1988). Other insecticides recommended at present are Dimethoate and Lindane at commercially recommended rates, but both negatively affect the ant. species predatory to the bug.

(ii) Biological control of P. wayi - P. wayi can be successfully controlled chemically. However, for practical, economic and environmental considerations other control measures must be developed. Biological control of P. wayi is possible using an ant species, Oecophylla longinoda Latreille, but successful establishment, maintenance, sustained growth and further colonizing activity of additional palms have not been achieved. More information are also required about the bug and the ant species themselves. Thus, further studies are conducted on the biology and ecology of both. Field observations and trials were also started. Further search for natural enemies of P. wayi is in progress. For instance, one strepsipteran parasite of adult bugs arid at least one species of egg parasitoid were noted. With O. longinoda, it was observed that the presence of competitor ants (Pheidole megacephala and Anoplolepis-E) hinders its establishment. A study was undertaken (Oswald, 1988) to suppress $\underline{P}$. magacephala in order to promote O. longinoda establishment using AMDRO (fire ant bait containing 8.88\% ai Hydramethylnon dissolved in refined soyabean oil co-solvent, impregnated unto pregelled defatted corn grits - Harlan, 1981 and Samway, 1985) gave good control against P. megacephala. Ground application also killed the colonies of the competitor ant and did not affect $\underline{O}$. longinoda. Thus, AMDRO application can be considered to suppress $\underline{P}$. megacephala in order to promote establishment of $\underline{O}$. longinoda. After the control of $\underline{P}$. megacephala, O. longinoda substantially colonized trees formerly occupied only by the competitor ant.

\section{Farming Systems Research}

Farming systems research (FSR) is a recently added component to NCDP activites. It will combine agronomic, economics and sociological research aspects in on-farm trials to investigate the applicability amd appropriateness of generated technology into the entire coconut farming enterprise,, with particular emphasis on smallholders. Current arid improved husbandry methods as well as different varieties will be compared and farmer responses monitored arid evaluated. The focal point of interest is to gain insight relevant for coconut production, with research emphasis on the interactions between the palms arid other elements of the farm organization such as cropping pattern, intercropping, animal husbandry arid the competition for available farm resources. Such interactions will be analyzed in the context of natural and socioenvironmental aspects.

FSR is viewed as a long-term undertaking in which reliable results can be expected only after three to five years when repeated observations of development over all seasons have been made. Prior to this, existing technical information will be reviewed/modified, thereafter formulated as extension packages arid made available to coconut growers. The experiences to be gained through the conduct of on-farm trials will help to assess the relevance of other research activities in relation to the overall prograrnme objective.

Specifically, the objectives of the FSR prograrnme are: 1) to describe the major farming systems in the coconut growing areas of Tanzania and understand their mode of operation; 2) to 
identify problems and constraints that hamper agricultural production; 3) to develop background information for planning and policy making; 5) to provide the basis for setting of research priorities; and 6) to train personnel in FSR methodologies. To achieve these objectives, the programme must establish close cooperation with active organizations and other on-going prograrnmes in the field of agricultural research and extension. The FSR programme will consist of two major components: 1) socio-economic farm management surveys; and 2) adaptive on-farm experiments.

The purpose of the surveys is of a diagnostic nature, ie, to detect problems and constraints. The results need not be statistically representative for a certain area or a certain group of farmers. It may be revealing to study a small group of farms households intensively than undertaking widely encompassing cross-sectional studies. The selected farmers should be typical smallholders, who depend on agriculture as their main source of livelihood. With this, the identified problems and contraints (once well understood) and their possible solutions should generally apply to other farmers under similar setting, as well.

On on-farm experiments, the main purpose is to test new technologles under farmer' conditions and see whether they are adapted not only to bio-physical conditions but also to farmers' goals and possibilities. On farm research, however, is an adaption process of technologies going through various cycles. In this case, the overriding question in on-farm experimentation is how the coexistence of coconut with other perennial or annual crops can be optimized according to farmers' goals and aspirations.

\section{UTILIZATION, PROCESSING AND MARKETING}

Coconut utilization in Tanzania hinges mainly on the supply of edible oil. Additional economic utilization of the nut and other useful parts of the tree are not sufficiently developed yet. About three-quarters of total production remains in the producing areas, where it serves as the major source of vegetable oil. The second largest product destination is the urban consurner, using up about one-fifth of the total freshnut supply. The share destined to industrial processing of nuts into copra and oil is less than $10 \%$.

Statistical information on vegetable oil supply and demand is scarce. Relating coconut production oil equivalent to the likely total vegetable oll consumption, coconut provides about $40 \%$ of the national vegetable oil requirement. It will continue to play a prominent role as the most important single source of vegetable oil. Unlike corittonseed, soyabean, and other potential competitors, coconut can be processed easily into oil or coconut milk of high oil content at household level. In Zanzibar, oil extraction efficiency by home processing was only about $30 \%$ below industrial processing standards and may be comparable to the present efficiency of copra-making and industrial oil milling in the Isles.

Zanzibar has maintained a separate stand in coconut marketing. The major objective of the government is to protect the local consurners. Copra prices were fixed and remained constant since the past few years. Recently, these prices were reviewed hopeful for a decision on an upward adjustment. Trade of freshnut is left to the private sector within the isles, however, export to the mainland requires permission from the government. During the recent years, the Zanzibar State Trading Corporation (ZSTC) and the MALD's Agricultural Corporation were also allowed to sell limited quantities of freshnuts to the mainland. ZSTC is the sole purchasing and sales agent for copra and also holds monopoly in the domestic and export trade of coconut oil.

Freshnut prices on both Mainland and Zanzibar, increased over the past years. Now, the relative price of freshnuts assures an advantage of about $300 \%$ over the price of copra to an average producer in the mainland. Within Zanzibar, freshnut and copra prices were about at parity levels until 
about 1984/85. Recently, the relative position of copra price was weakened, especially with freshnut trade possibilities to the mainland.

Market projections on the vegetaole oil sector may deviate widely. But it is recognized that the present demand is far from being satisfied by local supply. Import of vegetable oil by private sectors were allowed during the past five years. However, the foreign exchange required for these imports is not obtained from the central bank. Thus, this inflated retail prices for imported vegetable oil as traders budget high "opportunity costs" for foreign exchange. Increase in population would further distort the present vegetable oil supply and demand relationship. At a population growth of $3 \%$ p.a. and a constant market share of coconuts, production would have to more than double until 2010 only to keep pace with the present supply pattern (NCDP, 1987). Any growth in per capita income will lead to a correspondingly higher oil demand. Thus, the absorptive capacity of the local vegetable oil market is highly conducive for an expanded coconut production programme.

In the international scene, even under an aggressive coconut production promotion campaign, the coconut industry of Tanzania cannot be expected to register any significant econornic trade influence in the medium term. It is important to recognize, though, that present developments on the coconut sectors can play great roles in the country's effort to achieve self-sufficlency in a highly important commodity - coconut oil for food. Coconut byproduct utilization also offers great economic prospects. To take full advantage of the coconut industry in the long run, product utilization, processing and marketing must be dealt upon with equal vigour and enthusiam as any other coconut promotion campaign.

\section{ACKNOWLEDGEMENT}

Permission to submit this paper for publication granted by the Ministry of Agriculture and Livestock Development, Dar es Salaam, Tanzania is gratefully acknowledged.

\section{REFERENCES}

Agrar-und Hydrotechnik GmbH. 1980. Land Suitability Survey. Phase I. A Consultancy Report. National Coconut Development Programme, Dar es Salaam, Tanzania, pp. 182.

Allard, G. B. 1984. Pest Control Section - Annual Technical Report. National Coconut Development Programme, Dar es Salaam, Tanzania.

Balingasa, E. N. and Herz-Schweizer, M. 1983. Coconut population in Tanzania. Ann. Tech. Rept. National Coconut Development Programme, Dar es Salaam. Tanzania.

Balingasa, E. N. 1984. Coconut agriculture in Tanzania. Coconuts Today 11: 118:126.

Barkey, H. 1988. End of Tour Report. - Coconut Extension Service. National Coconut Development Programme, Dar es Salaam, Tanzania.

Bock, K. R., Ivory, M. H. and Adams, B. R. 1970. Lethal bole rot disease of coconut in East Africa. Ann. Appl. Biol. 66: 453-464.

Carlton, W. , E., Tidbury, G. E. and Walker, G. F. 1955. A study

of the more important soils of Zanzibar Proterate. East Afr. J. 21: 53-60.

FAO. 1974. FAO-UNESCO soil map of the world. Vol. 1 FAO/ UN, Rome and UNESCO Paris. 
Friedenchs, K. 1913. Zum heudgen Stande de Nasshornfaefer Bekaempfung in Samoa. Der Tropenpflanzer 17: 538-558.

Harlan, D. 1981. Large area tests of AC-217,300 bait for control of imported fire ants in Alabama, Lousiana and Texas. Southwestern Entomologist 6: 150-157.

Harries, 1-1. C. -1977. The Cape Verde region (1499 to 1549); the key to,coconut culture in the Western Hemisphere? Turrialba Quart. 37: 227-231.

Harries, H. C. 1978. The evolution, dissemination and classification of Cocos nucifera L. Bot. Rev. 44: 265-319.

Johns, R. 1938. a study of coconut palm yields and seed selection in Zanzibar. East Afr. J. 1986-194.

Julia, J.F. and Mariau, D. 1976. Recherches sur I'Oryctes monoceros Oliv. en Cote d'lvoire. I. Lutte biologigque. Le role de la plante de couverture. Oleagineux 31: 63-68.

Kaiza, D. A. 1987. History and Etiology of the Lethal Disease of Coconut Palm (Cocos nucifera L.) in Tanzania. MSc Thesis, Sokoine Univ. of Agric., Tanzania, pp. 138.

Keyserlingk, N. 1985. Evaluation Report on the Pest Control Sectlon. National Coconut Development Prograrnme, Dar es Salaam, Tanzania, pp. 68.

Lofchie, M. F. 1965. Zanzibar: Background to Revolution. Princeton Univ. Press, Princeton, New Jersey, pp. 316

Lomer, C. J. 1983. Biological control of Oryctes monoceros with Baculovirus oryctes in Seychelles. Final Report - Sychelles Coconut Pest Project, Seychelles pp. 62.

Morstatt, H. 1920. Die herzfaule der kokospalmen. Eine pflanzenpathologische Studie. Beiheff 3 zum Tropenflazer 23: 124.

NCDP. 1987. Prograrnme Phase 11 - Preparation Report. National Coconut Development Prograrnme, Dar es Salaam, Tanzania.

Nienhaus, F., Schuiling, M., Glem, G., Schinzer, U., and Spittel, A. 1981. Investigation on the etiology of the lethal disease of coconut palms in Tanzania. J. of Plant Diseases and Prot. 89(4): 185-193.

Oswald, S. 1988. Suitability of Endosulfan, Dimethoate and Formethanate for the ad hoc and integrated control of Pseudotheraptus wayi (Brown) Heteroptera (Coreidae). Rept. of Pest Control Section, NCDP, Zanzibar, pp. 11.

Oswald, S. 1988. Suitability of "AMDRO" fire ant bait against the brown ant Pheidole megacephala in an integrated control approach against the coconut bug Pseudotheraptus in Zanzibar. Rept. of Pest Control Section, NCDP, Zanzibar, pp. 12.

Paul, W. D. and Mwabukusi, H. J. 1983. Pest Control Section -Annual Technical Report. National Coconut Development Programme, Dar es Salaam, Tanzania, pp. 18.

Purrini, K. 1984. Pest Control Section - Annual Technical Report National Coconut Development Programme, Dar es Salaam, Tanzania, pp. 22. 
Purrini, K. 1984. On disease agents of insect pests of wild palms and forests in Tanzania. Paper pressented at the IUFRO Symposium "Man-made outbreaks of forest pests and their control", held Aug. 13-17, 1984 at the Univ. of Gottingen, Fed. Rep. of Germany.

Purseglove, J. W. 1972. Tropical Crops: Monocotyleclons. Longmans, pp. 540

Revington, T. M. 1936. Some notices on the Mafia Island Group (Mafia, Chole, Juani and Jibondo). Tanganyika Notes and Records 1: 33-37.

Robinson, A. E. 1937. The Shirazi colonization of East Africa. Tanganyika Notes and Records 3: 40-81.

Romney, D. H. 1987. Agronomy - Annual Technical Report. National Coconut Development Programme, Dar es Salaam, Tanzania, pp. 56.

Samways, M. J. 1985. Appraisal of the proprietary bait "AMDRO" for control on Southern African citrus. Citrus and Sub-trop. Fruit J. 621: 14-17.

Schuiling, M., Nienhaus, F and Kaiza, D. A. 1981. The syndrome in coconut palms affected by a lethal disease in Tanzania. J. Plant Dis. and Prot. 88: 665-667.

Schuiling, M. 1987. Research by Disease Control Section. Programme Phase 11 - Preparation Report. National Coconut Development Programme, Dar es Salaam, Tanzania, pp. 35.

Seguni, Z. S. K. and Lohr, B. 1987. Pest Control Section-Annual Technical Report. National Coconut Development Programme, Dar es Salaam, Tanzania, pp. 29.

Stein, H. 1905. Die kokosnuss und deren Bearbeitung in Deutsch-Ostafrika. Der Tropenpflanzer 9: 195-201.

Steiner, K. G., Nienhaus, F. and Marschall, K. G. 1977. Rickettsia-like organisms associated with a decline of coconut in Tanzania. z. Pflkrankh. PflSchutz 84: 345-351.

Steiner, K. G. 1978. Suspected lethal yellowing disease of coconut palms in Tanzania. FAO Plant Prot. Bull, 26: 10-12.

Swynnerton, R. J. M. 1946. The importance of the coconut industry on the Tanga Coast. East Afr. Agric. J. 17: 11-117.

Wuidart, W. 1980. Improvement of the Tanzanian Coconut Groves. IRHO Doc. No. 1503 pp. 71.

Vanderplank, F. L. 1959. Studies on the coconut pest, Pseudotheraptus wayi Brown (Coreidae) in Zanzibar. 1 - A method of assessing the darnage cause by the insect. Bull. Entorn. Res. 49. 559-585.

Way, M. J. 1953. Studies on Theraptus sp. (Coreldae): The cause of the gumming disease of coconuts en East Africa. Bull. Entorn. Res. 44: 657-669.

Way, M. J. 1983. Report on Consultant's Visit to Tanzania to Examine and Advise on the Pseudotheraptus wayi Problem on Coconut. National Coconut Development Prograrnme, Dar es Salaam, Tanzania, pp. 82. 
Zelazny, B. 1979. Loss in coconut yield due to Oryctes rhinoceros darnage. FAO Plant Prot. Bull. 27: 65-70. 